\title{
Energetic cost of sustained swimming in the late pelagic stages of reef fishes
}

\author{
Ilona C. Stobutzki* \\ Department of Marine Biology, James Cook University of North Queensland, Townsville, Queensland 4811, Australia
}

\begin{abstract}
The late pelagic stages of reef fishes are capable of swimming substantial distances which may significantly modify their dispersal. The energetic cost of this swimming, at $13.5 \mathrm{~cm} \mathrm{~s}^{-1}$, was measured for the late pelagic stages (mean total length ranging from 10.8 to $22.4 \mathrm{~mm}$ ) of 9 species from 4 reef fish families (Pomacentridae, Pomacanthidae, Chaetodontidae and Lethrinidae). Of the potential sources of energy (lipid, carbohydrate and protein), all were utilised, but lipid appeared to be the most energetically important across the species. Lipid levels decreased significantly in 5 of the 9 species. The decrease and the relative percentage of energy lost in the form of lipid was greater than for carbohydrate and protein. The pattern of energy utilisation varied among species. The greatest decrease in energy stores was seen in the heaviest species, which swam for the longest duration (the chactodontids and lethrinid), showing up to $72 \%$ decrease in lipid. $66 \%$ decrease in carbohydrate and $39 \%$ decrease in protein. The lighter species, which swam for shorter time periods (the pomacentrids and the pomacanthid), showed comparatıvely little change in energy reserves after swimming. Initial levels of energy reserves correlated with distance swum and were greatest in the heavier species.
\end{abstract}

KEY WORDS: Reef fish Condition Energetics Swimming Pre-settlement. Dispersal

\section{INTRODUCTION}

The majority of reef fishes have a bipartite lifecycle with a pelagic early life stage and a benthic reef associated stage (Leis 1991). The pelagic early life stage is the primary dispersal phase, as the reef associated stage is relatively site attached (Sale 1991). Recent work on the sustained swimming abilities of the late pelagic stages of reef fishes has shown that they are capable of swimming substantial distances (Stobutzki \& Bellwood 1997); pre-settlement acanthurids swam an average of $94 \mathrm{~km}$ in a single swimming bout over $8 \mathrm{~d}$. This swimming has the potential to substantially alter the dispersal patterns of the pelagic stages, which will determine the number of recruits available for settlement on reefs (Sale 1991). Active swimming by the pelagic stages may therefore influence the distribution and demography of reef fish populations.

\footnotetext{
-Address for correspondence: CSIRO Marine Research, PO Box 120, Cleveland, Queensland 4163, Australıa.
}

Given the potential ecological importance of sustained swimming in the pelagic stages, the energetic cost of this swimming should be examined. In general swimming is energetically expensive for fishes; since their maintenance requirements are comparatively low, locomotion forms a major part of their energy budget (Brett \& Groves 1979). Swimming has been shown to increase the metabolic rate of fishes by up to 15 -fold (Beamish 1978). Therefore, given the potentially large metabolic cost of swimming and the long distances swum by the late pelagic stages the question arises: what effect do these swimming episodes have on their energy stores?

In the pelagic environment the energetic cost of swimming may determine the extent to which different taxa modify their dispersal by directional swimming. If swimming episodes of the type recorded in Stobutzki \& Bellwood (1997) exhaust all available energy stores, they may be detrimental to the growth or survival of the pelagic stages. This energetic cost may also influence post-settlement survival and growth on the reef There has been an increasing 
number of studies focusing on the biochemical condition of fish (Ferron \& Leggett 1994) and in particular reef fish, just prior to and after settlement (e.g. McCormick \& Molony 1992, 1993, 1995, Kerrigan 1996). These have arisen from the assumption that condition is important at both the population and the individual level. For populations, the strength of recruitment events could be influenced by relatively small differences in condition during the pelagic stage (Miller et al. 1988, Beyer 1989, Houde 1989), while an individual's condition may determine the probability of survival after settlement (Chambers et al. 1988). Research has, therefore, focused on the variation in condition and the factors which influence this, such as temperature (McCormick \& Molony 1995) and food availability (McCormick \& Molony 1992, Kerrigan 1994). The extent of sustained swimming during the pelagic stage could also be a major factor contributing to the variation in condition of recruits.

Given the potentially wide implications of the energetic cost of sustained swimming to the pelagic stages, the aim of the present study was to determine the extent and nature of the utilisation of energy stores in the late pelagic stages of reef fishes when swum to exhaustion. The change in total body constituents (protein, lipid and carbohydrate) due to sustained swimming was examined by comparing freshly collected fish with those swum to exhaustion. The effect of swimming on energy stores was compared across 9 species from 4 families (Pomacentridae, Pomacanthidae, Chaetodontidae and Lethrinidae).

\section{MATERIALS AND METHODS}

Fish were collected using light traps (Stobutzki \& Bellwood 1997) during the summer recruitment period, October and January, 1994-95 and 1995-96 at Lizard Island, Great Barrier Reef, Australia (14 $14^{\prime} \mathrm{S}, 145^{\circ}$ $27^{\prime} \mathrm{E}$ ). All fish were late pelagic stage individuals, primarily juveniles (Leis 1991) and competent to settle on the reef. They had fully developed swim bladders and swam in a carrangiform manner (Lindsey 1978). Details of their body morphology are provided in Stobutzki \& Bellwood (1997). Comparisons were made between fish swum to exhaustion and fish which had not been swum (controls). The controls provide an estimate of the levels of biochemical constituents prior to the swimming bout. Fish were selected randomly to be swum or controls and matched for size (there was no significant difference in total length, TL, between the controls and swum fish; ANOVA $F_{1,283}=3.12, \mathrm{p}=$ 0.078). The species examined were as follows (number of controls and swum fish respectively in parentheses): the pomacentrids: Chromis sp. (most likely C. viridis and/or C. atripectoralis) $(21,17)$, Neopomacentrus sp. 2 (most likely $N$. azysron) (22, 20), Pomacentrus amboinensis $(19,17), P$. chrysurus $(20,16)$ and $P$. moluccensis $(21,17)$; the chaetodontids: Chaetodon plebius $(21,6)$ and Chelmon rostratus $(16,10)$; a pomacanthid: Pomacanthus sexstriatus $(7,13)$; and a lethrinid: Lethrinus atkinsoni $(21,21)$.

Experimental fish were maintained in darkened aquaria with flowing water until swum. Fish were swum at $13.5 \mathrm{~cm} \mathrm{~s}^{-1}$ in a swimming chamber at $30.2 \pm$ $0.7^{\circ} \mathrm{C}( \pm \mathrm{SE})$ until they fatigued, i.e. they could no longer maintain position against the current (Stobutzki \& Bellwood 1997). This speed was chosen as it approximates the mean current speed around Lizard Island (Frith et al. 1986). The time until the fish fatigued was recorded and the equivalent distance travelled calculated (i.e. $13.5 \mathrm{~cm} \mathrm{~s}^{-1}=0.486 \mathrm{~km} \mathrm{~h}^{-1}$ ). Once a fish had fatigued it was immediately anaesthetised in cold water, had its total length and blotted wet weight recorded, and was then frozen in liquid nitrogen.

Control specimens were killed within 1 h of capture in the same manner, were anaesthetised, had their TL and blotted wet weight measured and then were frozen. Assays were performed on whole fish due to their small size. Prior to analysis each fish was freezedried to a constant weight and its dry weight and water content calculated. Each fish was then homogenised in $100 \mathrm{mM}$ sodium chloride $(5 \mathrm{ml}$ volume was used for fish $<50 \mathrm{mg}$ dry weight and $10 \mathrm{ml}$ for fish $>50 \mathrm{mg}$ dry weight). Three $1.5 \mathrm{ml}$ aliquots were then taken for biochemical analysis, 1 aliquot for each assay. Total protein content was determined colorimetrically following Bradford (1976). Total lipid was determined using a chloroform:methanol extraction following Mann \& Gallager (1985). Total carbohydrate was determined by a modification of the method of Mann \& Gallager (1985), as described by McCormick \& Molony (1992). Analyses were carried out in duplicate, with blanks and standards run simultaneously. Levels of the biochemical constituents are expressed as $m g \mathrm{~g}^{-1}$ dry body weight

\section{DATA ANALYSIS}

The effect of species and treatment (swum or controls) on each variable (water content, dry weight, total protein, total lipid and total carbohydrate) was examined using separate 2-way ANOVAs (Zar 1984) Prior to analysis the homogeneity of variances and the normality of the data were examined graphically (Zar 1984). Tukey's HSD tests were used to interpret the significant differences between means (Zar 1984).

To examine the potential causes of the different responses among species, Pearson's correlations (Zar 
1984) were calculated between all variables in addition to TL and distance swum. This was performed separately for the experimental fish and controls. Correlations among the control fish, between the levels of biochemical constituents and distance swum by experimental fish, used the mean distance swum by each species. Prior to analysis the data were examined graphically to check for linearity, normality and homoscedasticity (Zar 1984).

Estimates of the percentage loss in each biochemical constituent and dry weight for each species were obtained from the difference between the mean for the controls and the experimental fish. Pearson's correlations (Zar 1984) were calculated between the percentage decrease in the biochemical constituents and the mean distance swum across the species; the linearity, normality and homoscedasticity of the data were verified graphically (Zar 1984)

To obtain estimates of the average energy loss due to swimming for each species, the energetic value of each biochemical constituent was calculated by multiplying the levels by the calorific value, 36.42, 23.86 and $17.16 \mathrm{~kJ} \mathrm{~g}^{-1}$ for lipid, protein and carbohydrate respectively (Brett \& Groves 1979). This enabled an estimate of mean energy loss to be calculated by comparing the difference between the mean for control and for swum fish. This was then converted to the energetic cost of swimming $1 \mathrm{~km}$ per unit dry body weight.

\section{RESULTS}

The mean time until the experimental fish fatigued varied nearly 4 -fold among species (Table 1), from $35.9 \mathrm{~h}$ for Pomacentrus moluccensis to $137.6 \mathrm{~h}$ for Lethrinus atkinsoni, which is the equivalent of swimming $17.5 \mathrm{~km}$ and $66.88 \mathrm{~km}$ respectively. On the basis of dry weight, the species form 2 broad groups
(Table 1, Fig 1). The pomacentrid species are relatively small, with dry weights of less than $13.7 \mathrm{mg}$. while the chaetodontids and the lethrinid are much heavier, with dry weights of greater than $33 \mathrm{mg}$. The pomacanthid has an intermediate weight of $25.2 \mathrm{mg}$. This division mirrors the differences in swimming abilities (Table 1); the pomacentrids all swam less than $27 \mathrm{~km}$, while the chaetodontids and the lethrinid swam further than $42 \mathrm{~km}$. The pomacanthid again falls

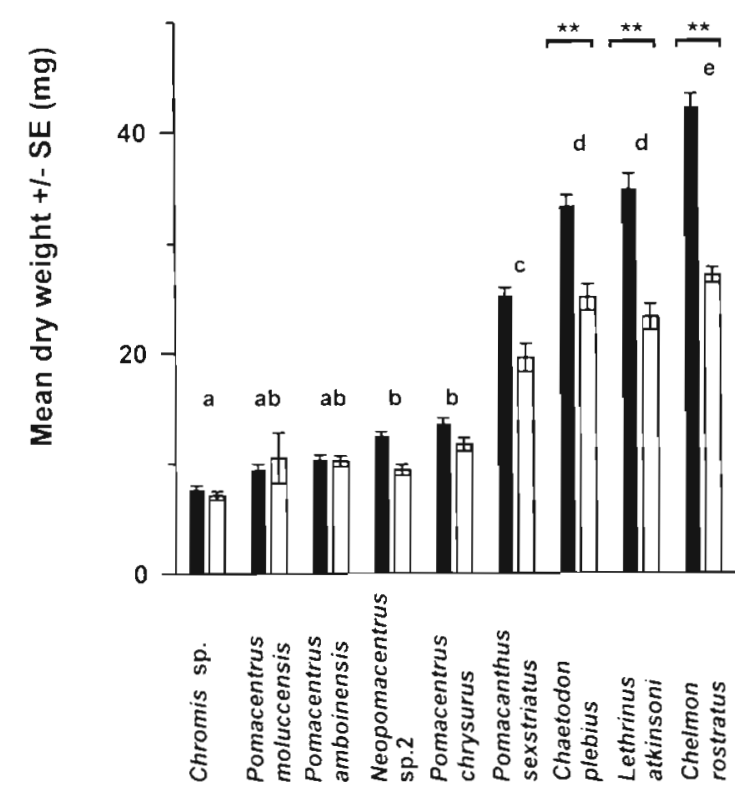

\section{Species}

Fig. 1. Mean dry body weight of controls (solid bars) and swum fish (open bars) in each species. ** Signifies a significant difference between the control and swum means for that species. $a, b, c, d$ and e refer to the groups of control weights which were not found to be significantly different from the Tukey comparisons

Table 1. Mean dry weight and total length (TL) of control individuals in each species and the time until exhausted and the equivalent distance swum at $13.5 \mathrm{~cm} \mathrm{~s}^{-1}$, for swum individuals. SE: standard error

\begin{tabular}{|c|c|c|c|c|c|c|c|c|}
\hline Species & $\begin{array}{c}\text { Mean dry } \\
\text { weight (mg) }\end{array}$ & $\mathrm{SE}$ & $\begin{array}{c}\mathrm{TL} \\
(\mathrm{mm})\end{array}$ & $\mathrm{SE}$ & $\begin{array}{l}\text { Time until } \\
\text { exhausted (h) }\end{array}$ & $\mathrm{SE}$ & $\begin{array}{c}\text { Distance } \\
\text { swum (km) }\end{array}$ & SE \\
\hline Chromis sp. & 7.7 & 0.26 & 10.8 & 0.13 & 39.3 & 6.1 & 19.1 & 3.0 \\
\hline Pomacentrus moluccensis & 9.5 & 0.46 & 13.6 & 0.16 & 35.9 & 6.6 & 17.5 & 3.2 \\
\hline Pomacentrus amboinensis & 10.6 & 1.87 & 14.7 & 0.20 & 54.6 & 11.0 & 26.1 & 5.4 \\
\hline Neopomacentrus sp. 2 & 12.5 & 0.39 & 14.4 & 0.16 & 44.7 & 6.9 & 21.7 & 3.4 \\
\hline Pomacentrus chrysurus & 13.7 & 0.49 & 16.2 & 0.15 & 41.0 & 8.5 & 19.9 & 4.1 \\
\hline Pomacanthus sexstriatus & 25.2 & 0.66 & 15.8 & 0.19 & 73.9 & 15.4 & 35.9 & 7.5 \\
\hline Chaetodon plebius & 33.3 & 0.93 & 13.3 & 0.13 & 104.4 & 11.3 & 50.7 & 5.5 \\
\hline Lethrinus atkinsoni & 34.8 & 1.24 & 22.4 & 0.27 & 137.6 & 7.6 & 66.9 & 3.7 \\
\hline Chelmon rostratus & 42.1 & 1.04 & 18.9 & 0.24 & 87.7 & 9.8 & 42.6 & 4.8 \\
\hline
\end{tabular}


between these 2 extremes. This division is not as clear when looking at TL, as there is substantial overlap in TL between the heavy and the lighter species (Table 1).

Water content was on average $73 \%$ wet weight and not found to vary significantly among species or between swum fish and controls, nor was there a significant interaction detected (Table 2). Dry weight, protein, lipid and carbohydrate content (Appendix 1) varied significantly between swum and control fish, but this was not constant across the species; that is, there was a significant interaction for all variables (Table 2).

On average, swum individuals of Lethrinus atkinsoni, Chelmon rostratus and Chaetodon plebius showed significantly lower dry weights than the controls (Fig. 1). Swum fish in these species were over $25 \%$ lighter than

a)

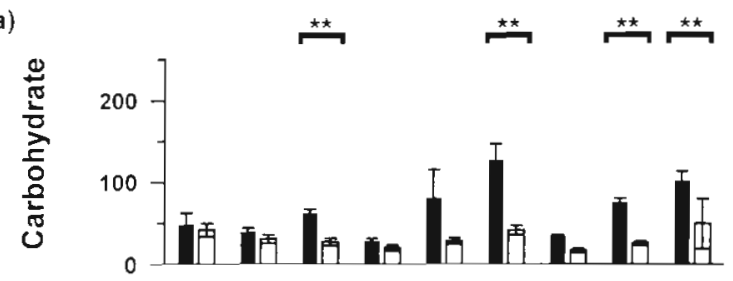

b)

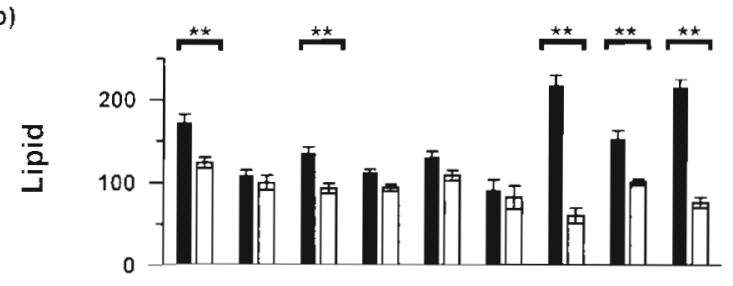

c)

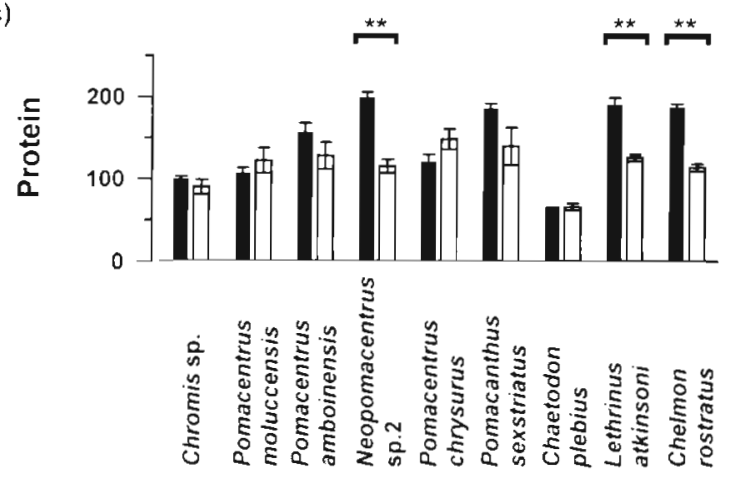

Species

Fig. 2. Mean weight of each constituent: (a) carbohydrate, (b) lipid and (c) protein (mg g $\mathrm{g}^{-1}$ dry body weight $\pm \mathrm{SE}$ ) of controls (solid bars) and swum fish (open bars) in each species.

* * Signifies a significant difference between the control and swum means for that species the controls; C. rostratus showed the greatest difference, with the swum fish over $35 \%$ lighter than controls. The lighter species (the pomacentrids and the pomacanthid) showed no significant difference between swum fish and controls, although most swum fish had lower mean dry weights (Fig. 1). This loss of dry weight is reflected in the change in condition factor between swum and control fish (Appendix 1).

Protein, lipid and carbohydrate were all utilised during swimming but the extent varied among the species (Fig. 2). Carbohydrate and lipid showed the greatest decreases between control and experimental fish (Fig. 2). Chelmon rostratus and Lethrinus atkinsoni were the only species which showed a significant decrease in all 3 components. For $C$. rostratus the greatest difference was seen in lipid content, swum fish had $64.4 \%$ less lipid than controls, while carbohy-

a)

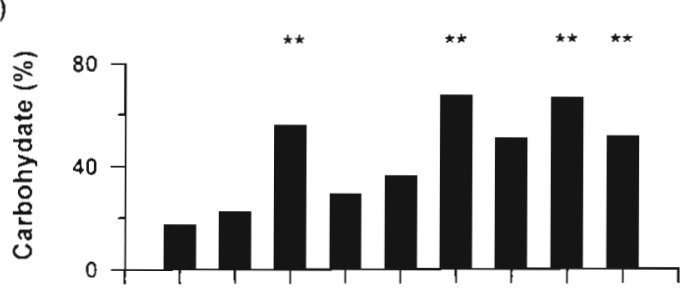

b)

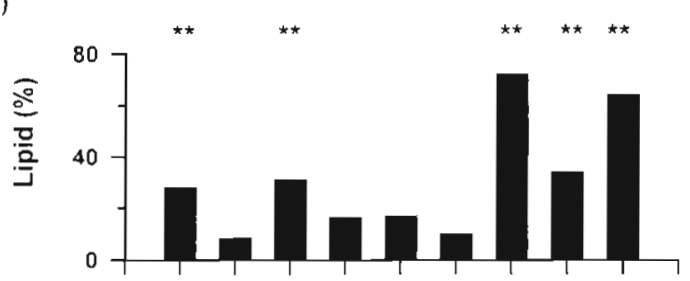

c)

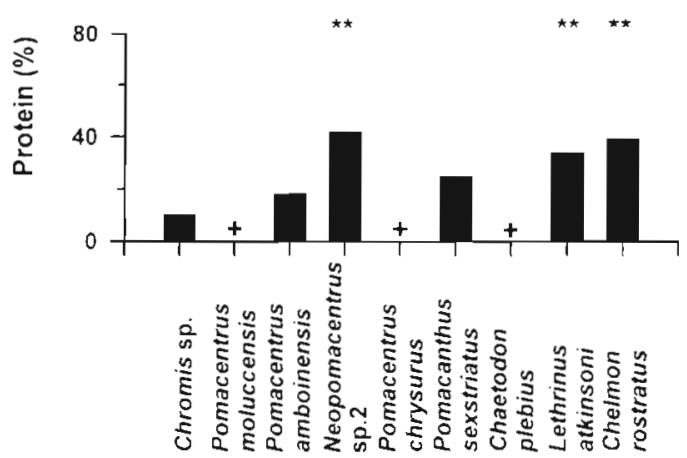

Species

Fig. 3. Percentage decrease in weight of (a) carbohydrate, (b) Iipid and (c) protein between the swum and control fish in each species. * Indicates where the difference was significant, + indicates where there was an apparent increase 
Table 2. ANOVA results for the effect of species, treatment (swum or control) and any interaction, on the dependent variables: water content, dry body weight, total protein, lipid and carbohydrate. Probabilities are given in parentheses; "indicates significance at $\mathrm{p}=0.05, \cdots$ indicates significance at $\mathrm{p}=0.0001$

\begin{tabular}{|c|c|c|c|c|c|c|}
\hline Source of variation & & $\%$ water & Dry body weight & Total protein & Total lipid & Total carbohydrate \\
\hline Treatment $(1,287 \mathrm{df})$ & $F$ & $\begin{array}{c}0.56 \\
(0.455)\end{array}$ & $\begin{array}{l}111.86^{\circ} \\
(<0.0001)\end{array}$ & $\begin{array}{c}35.27^{*} \\
(<0.0001)\end{array}$ & $\begin{array}{l}174.09 * \\
(<0.0001)\end{array}$ & $\begin{array}{c}75.02 * \\
(<0.0001)\end{array}$ \\
\hline Species (8.287 df) & F & $\begin{array}{c}1.72 \\
(0.093)\end{array}$ & $\begin{array}{l}214.57 \cdots \\
k 0.0001\}\end{array}$ & $\begin{array}{c}17.84^{\circ} \\
(<0.0001)\end{array}$ & $\begin{array}{c}10.19^{*} \\
(<0.0001)\end{array}$ & $\begin{array}{c}13.23 \cdots \\
\{<0.0001\}\end{array}$ \\
\hline Interaction $(8,287 \mathrm{df})$ & $F$ & $\begin{array}{c}0.99 \\
(0.446)\end{array}$ & $\begin{array}{c}15.99 \cdot \\
k<0.0001)\end{array}$ & $\begin{array}{c}8.74 \cdots \\
(<0.0001)\end{array}$ & $\begin{array}{c}15.15^{*} \\
(<0.0001)\end{array}$ & $\begin{array}{c}7.02 \cdot \cdot \\
(<0.0001)\end{array}$ \\
\hline
\end{tabular}

drate and protein were lower by 51.3 and $39.4 \%$ respectively (Fig. 3). L. atkinsoni showed a greater proportion of carbohydrate lost $(66 \%)$, while both protein and lipid decreased by approximately $34 \%$ (Fig. 3). Chaetodon plebius showed a similar pattern of decrease in lipid to $C$. rostratus, with swum fish having $72.2 \%$ lower lipid than controls (Fig. 3), but displayed no significant decrease in protein or carbohydrate (Fig. 2). In the lighter species (the pomacentrids and the pomacanthid) the change in levels of constituents was much less dramatic (Fig. 2). Pomacanthus sexstriatus showed a marked decrease in carbohydrate, with swum fish having $67 \%$ lower carbohydrate than controls (Fig. 3), but there was no significant change detected in lipid or protein (Fig 2). Pomacentrus amboinensis showed a decrease in carbohydrate and lipid (56 and 31\% respectively) (Fig. 3); Chromis sp. showed a decrease in lipid $(28 \%)$ and Neopomacentrus sp. 2 a decrease in protein (42\%) (Fig. 3). For the species Pomacentrus moluccensis and Pomacentrus chrysurus no significant decreases were detected in any of the biochemical constituents

All 3 biochemical constituents displayed the greatest decreases in the species with the highest original levels (Fig. 4). The 4 species with the highest carbohydrate levels initially (Fig. 4) displayed significant losses of between 51 and $67 \%$, while no significant decreases were detected for the species with lower initial levels. The significant decreases seen in lipid content also occurred in the 5 species with the highest initial levels, where lipid decreased by between 31 and $72 \%$ after swimming The species with low initial levels of lipid a) Carbohydrate
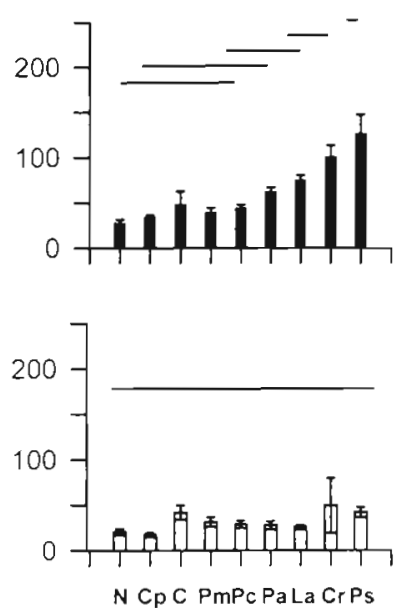

b) Lipid
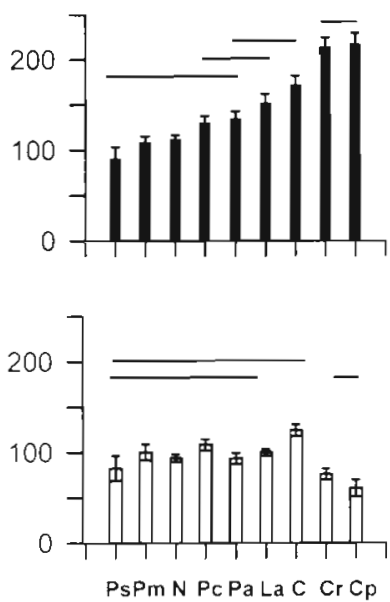

Species c) Protein
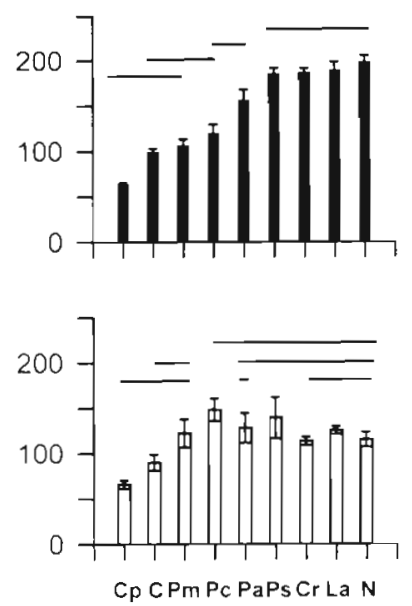

Fig. 4. Mean weight ( $\mathrm{mg} \mathrm{g}^{-1}$ dry body weight $\pm \mathrm{SE}$ ) of each constituent: (a) carbohydrate, (b) lipid and (c) protein, in each species before (solıd bars) and after (open bars) swimming. Order of species changes between the constituents and is determined by the weight of constituents in the controls, pror to swimming. Lines represent non significant differences from the Tukey tests. Species are C: Chromis sp.; Pm: Pomacentrus moluccensis; Pa: Pomacentrus amboinensis; N: Neopomacentrus sp. 2; Pc: Pomacen-

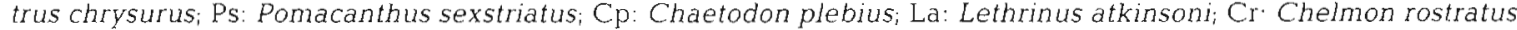




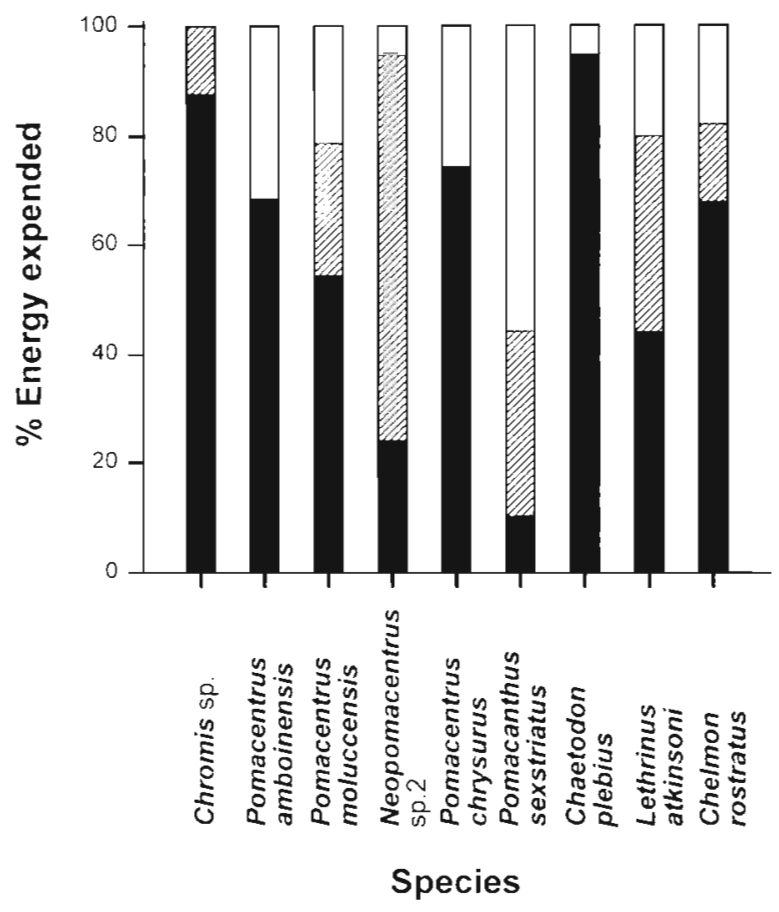

Fig. 5. Percentage energy lost in the form of lipid (solid bars), protein (shaded bars) and carbohydrate (open bars) in each species

only displayed decreases of between 9 and $17 \%$. A similar pattern is evident for protein although the amounts lost are much lower, with only 39 to $42 \%$ decreases in species with the highest initial levels. Species with low initial protein levels showed no detectable loss or a relatively small one. Prior to swimming, lipid and carbohydrate content varied widely among the species (Fig. 4). After swimming, however, this variation was greatly reduced. Carbohydrate levels in the swum fish showed no detectable difference among species and lipid levels also showed little difference (Fig. 4). Protein content displayed some decrease in variation among the species after swimming but not to the same extent as lipid and carbohydrate (Fig. 4). Swimming appeared to decrease the levels of energy stores to a consistent level across the species.

While both carbohydrate and lipid displayed large percentage decreases (Fig. 5) the energetic importance of lipid is clear from the fact that in general the percentage of energy lost in the form of lipid was much greater than that of the other constituents. However, differences among species are still evident. For Lethrinus atkinsoni the amount of energy lost to lipid is only slightly greater than that lost in the form of protein. In Neopomacentrus sp. 2 the energy lost as protein was greatest, while for Pomacanthus sexstriatus the major- a)

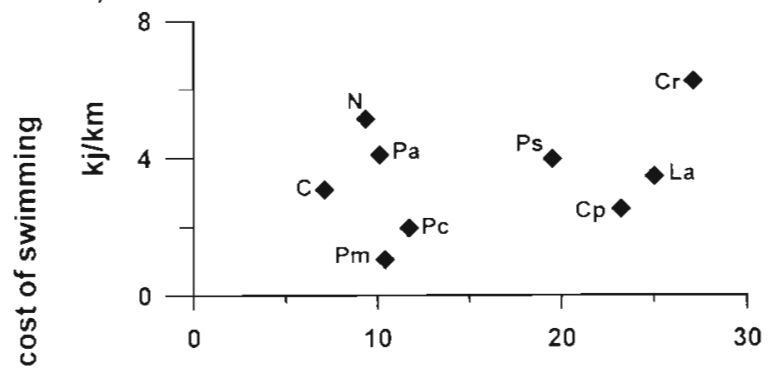

b)

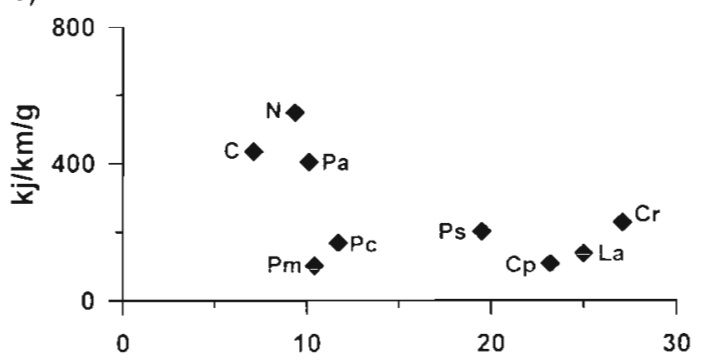

Mean dry body weight (mg)

Fig. 6. Mean cost of swimming per $\mathrm{km}$, against mean body weight for each species (a) in terms of $\mathrm{kJ} \mathrm{km}^{-1}$ and (b) in terms of $\mathrm{kJ} \mathrm{km}^{-1} \mathrm{~g}^{-1}$ body weight. Species abbreviations as in Fig. 4

ity of energy was lost in the form of carbohydrates. There was no clear relationship with dry weight in the overall cost of swimming $1 \mathrm{~km}$, estimated in terms of the total energy consumed (Fig. 6a). The energetic cost of swimming $1 \mathrm{~km}$ unit $^{-1}$ body weight, however, appears to decrease with increasing dry weight of the fish (Fig. 6b).

Correlations between the variables for the control fish show a variety of relationships (Table 3). Across all species dry weight was significantly correlated to TL (Table 3). Dry weight was also positively correlated to all 3 biochemical constituents (Table 3 ). The relationship with protein, however, was much weaker than that with lipid or carbohydrate. The relationship between the biochemical constituents and TL differs, with significant correlations only occurring with protein and carbohydrate (Table 3). Protein was more strongly correlated to TL than dry weight, while lipid was more strongly correlated with dry weight. The strength of the correlations of both TL and dry weight with carbohydrate was similar The biochemical constituents themselves were correlated with one another; protein increased with increasing carbohydrate but decreased with increasing lipid, although the latter relationship was weaker. 
Table 3. Correlation matrix between variables across species for control fish $(n=168)$. Symbol definitions as in Table 2

\begin{tabular}{|c|c|c|c|c|c|c|}
\hline Source of variation & $\%$ water & Dry body weight & Total length & Total protein & Total lipid & Total carbohydrate \\
\hline Distance swum & $\begin{array}{c}0.145 \\
(0.060)\end{array}$ & $\begin{array}{c}0.846^{*} \\
(<0.0001)\end{array}$ & $\begin{array}{c}0.691 * \\
(<0.0001)\end{array}$ & $\begin{array}{c}0.165^{\circ} \\
(<0.0001)\end{array}$ & $\begin{array}{c}0.372 \cdots \\
(<0.0001)\end{array}$ & $\begin{array}{c}0.337^{*} \\
(<0.0001)\end{array}$ \\
\hline$\%$ water & & $\begin{array}{c}0.075 \\
(0.336)\end{array}$ & $\begin{array}{c}0.289 \cdot \\
(<0.0001)\end{array}$ & $\begin{array}{c}0.123 \\
(0.114)\end{array}$ & $\begin{array}{c}0.002 \\
(0.974)\end{array}$ & $\begin{array}{c}0.320 \cdots \\
(<0.0001)\end{array}$ \\
\hline Dry weight & & & $\begin{array}{c}0.656^{\circ} \\
(<0.0001)\end{array}$ & $\begin{array}{c}0.158^{\circ} \\
(0.041)\end{array}$ & $\begin{array}{c}0.481{ }^{*} \\
(<0.0001)\end{array}$ & $\begin{array}{c}0.434 \\
(<0.0001)\end{array}$ \\
\hline Total length & & & & $\begin{array}{c}0.529 \cdot \\
(<0.0001)\end{array}$ & $\begin{array}{c}0.041 \\
(0.603)\end{array}$ & $\begin{array}{c}0.451 \cdots \\
(<0.0001)\end{array}$ \\
\hline Total protein & & & & & $\begin{array}{l}-0.212 * \\
(<0.0001)\end{array}$ & $\begin{array}{c}0.378 \cdot \cdot \\
(<0.0001\}\end{array}$ \\
\hline Total lipid & & & & & & $\begin{array}{c}0.131 \\
(0.090)\end{array}$ \\
\hline
\end{tabular}

Table 4. Correlation matrix between variables across species for fish which have been swum $(n=137)$. Notation follows Table 2

\begin{tabular}{|c|c|c|c|c|c|c|}
\hline Source of variation & Dry body weight & Total length & Distance swum & Total protein & Total lipid & Total carbohydrate \\
\hline$\%$ water & $\begin{array}{l}-0.55^{\circ} \\
(<0.0001)\end{array}$ & $\begin{array}{r}0.109 \\
(0.206)\end{array}$ & $\begin{array}{c}0.050 \\
(0.561)\end{array}$ & $\begin{array}{c}0.049 \\
(0.571)\end{array}$ & $\begin{array}{r}0.194^{\circ} \\
(0.023)\end{array}$ & $\begin{array}{c}-0.013 \\
(0.884)\end{array}$ \\
\hline Dry weight & & $\begin{array}{l}-0.012 \\
(0.889)\end{array}$ & $\begin{array}{c}0.051 \\
(0.551)\end{array}$ & $\begin{array}{c}0.148 \\
(0.083)\end{array}$ & $\begin{array}{c}-0.136 \\
(0.113)\end{array}$ & $\begin{array}{c}0.116 \\
(0.176)\end{array}$ \\
\hline Total length & & & $\begin{array}{c}0.666 * \\
(<0.0001)\end{array}$ & $\begin{array}{c}0.153 \\
(0.076)\end{array}$ & $\begin{array}{c}-0.136 \\
(0.115)\end{array}$ & $\begin{array}{c}-0.049 \\
(0.570)\end{array}$ \\
\hline Distance swum & & & & $\begin{array}{c}-0.196^{\circ} \\
(0.022)\end{array}$ & $\begin{array}{r}-0.263^{\circ} \\
(0.002)\end{array}$ & $\begin{array}{c}-0.044 \\
(0.612)\end{array}$ \\
\hline Total protein & & & & & $\begin{array}{c}0.314^{*} \\
(<0.0001)\end{array}$ & $\begin{array}{c}0.108 \\
(0.207)\end{array}$ \\
\hline Total lipid & & & & & & $\begin{array}{c}0.213^{\circ} \\
(0.012)\end{array}$ \\
\hline
\end{tabular}

When the mean distance swum by species is compared with the levels of variables in the controls, the strongest relationships were with dry weight and TL, both of which displayed a positive correlation (Table 3). Levels of both lipid and carbohydrate in the controls were also positively correlated with mean distance swum, while protein levels showed no relationship with mean distance swum (Table 3 ). This suggests that species with higher initial levels of lipid and carbohydrate could cover greater distances (Table 3).

Fish which had been swum showed very different relationships between the variables (Table 4) than those seen in the controls (Table 3). Dry weight was no longer significantly correlated with the levels of the biochemical constituents. This is most likely due to the differing response of the species to swimming. Species with the largest dry weights showed the greatest decrease in energy stores (Figs. 2 \& 3), while lighter species showed little change, resulting in relatively constant levels of the constituents across all species after swimming (Fig. 4), despite differences in dry weight. This result differs from the controls, in which levels of the energy stores increased with increasing weight (Table 3). The correlations seen with TL in the controls (Table 3) were likewise disrupted after swimming (Table 4), with levels of protein, lipid and carbohydrate being weakly negatively correlated to distance swum (Table 4). Again the weak relationship is probably due to the fact that the levels of constituents in all species were similar after swimming.

When the mean distance swum was compared to the percentage loss of dry weight and each biochemical constituent across the species, the only significant correlations were with dry weight and carbohydrate decrease (Table 5). With increasing distance swum there was an increase in the percentage of dry weight and 
Table 5 . Correlation matrix among the variables: mean percentage dry weight lost, the loss in each brochemical constituent and distance swum ( $\mathrm{n}=9$ ). Symbol definitions as in Table 2

\begin{tabular}{|c|c|c|c|c|}
\hline Source of variation & $\%$ dry body weight lost & $\%$ protein lost & $\%$ lipid lost & $\%$ carbohydrate lost \\
\hline Distance swum & $\begin{array}{c}0.754^{\circ} \\
(0.019)\end{array}$ & $\begin{array}{c}0.339 \\
(0.373)\end{array}$ & $\begin{array}{c}0.588 \\
(0.096)\end{array}$ & $\begin{array}{c}0.7513^{\circ} \\
(0.020)\end{array}$ \\
\hline$\%$ dry weight lost & & $\begin{array}{c}0.663 \\
(0.052)\end{array}$ & $\begin{array}{c}0.521 \\
(0.150)\end{array}$ & $\begin{array}{c}0.565 \\
(0.113)\end{array}$ \\
\hline$\%$ protein lost & & & $\begin{array}{c}0.065 \\
(0.869)\end{array}$ & $\begin{array}{c}0.372 \\
(0.324)\end{array}$ \\
\hline$\%$ lipid lost & & & & $\begin{array}{c}0.295 \\
(0.441)\end{array}$ \\
\hline
\end{tabular}

carbohydrate lost. The reduction in lipid and protein did not correlate strongly with distance swum (Table 5).

\section{DISCUSSION}

The degree to which energy sources were utilised by the late pelagic stages varied among species, but it was clear that all 3 sources (protein, lipid and carbohydrate) could support sustained swimming (Fig. 2). Carbohydrate and lipid appeared to be the most important, as they displayed the greatest percentage decreases across the species (Fig. 3). However, in all but 2 species, the greatest percentage of energy was lost in the form of lipid (Fig. 5). This pattern of utilisation agrees with previous studies of the energetics of swimming in fishes, which suggest that the energy for sustained swimming comes primarily from aerobic metabolism, utilising carbohydrate and lipid as the major energy sources (reviewed by Bilinski 1974, Beamish 1978). Protein tends to be conserved as it forms the structure of the muscles (Loughna \& Goldspink 1984). The fact that protein levels displayed a stronger correlation with TL than wet weight (Table 3 ) is indicative of its structural function. In comparison, lipid and carbohydrate levels correlated strongly with wet weight (Table 3), as expected due to their role as energy stores. In general, lipid was the most energetically importan: store due to its high calorific value and the fact that carbohydrate levels are characteristically low in fishes (Beamish 1978) Previous research also suggests that there is an inverse relationship between water and lipid content (Love 1970). This was not apparent in the present study, as while lipid decreased after swimming (Fig. 3) no corresponding increase in water content was detected.

Contrary to the general trend, significant decreases in protein content were seen in 3 species (Fig. 3) and for Neopomacentrus sp. 2 protein was the primary energy source (Fig. 5). These decreases in protein, however, were much less than those observed in carbohydrate and lipid (Fig. 3), up to $42 \%$, compared to $72 \%$ in lipid. Neopomacentrus sp. 2 had the lowest carbohydrate level of all species and the third lowest initial lipid content (Fig. 4). These specimens may therefore not have had sufficient alternative energy stores available to enable them to conserve their protein.

The majority of studies of swimming energetics in fishes have focused on determining levels of oxygen consumption and hence metabolic rate (e.g. Webb 1971, Dabrowski et al. 1986, Beamish 1990). While this approach is useful, it provides little information on the energy substrates utilised and has been shown to markedly underestimate the depletion of energy stores (Krueger et al. 1968, Beamish 1978). In the present study the pattern and extent of utilisation of energy stores varied among the species, in relation to their initial weight and original levels of energy stores. In general, the heavier species (the chaetodontids and the lethrinid) had higher original levels of energy stores (Fig. 2), swarn for long time periods (Table 1) and displayed a correspondingly larger proportional decrease in their energy stores (Fig. 3). In comparison, the smaller species (the pomacentrids and the pomacanthid) had lower original energy levels (Fig 2), did not swim as long as did the heavier species (Table 1) and displayed much lower proportional losses of their energy stores (Fig. 3). Where large proportional losses in an energy store of a lighter species were detected, they were associated with high original levels of the constituent (Fig. 4). Weicht differences among the species initially appear to influence the levels of energy stores present and therefore also influence sustained swimming abilities and the losses detected.

Prior to swimming there were substantial differences in all biochemical constituents among the species (Fig. 4). These differences, however, were greatly reduced after swimming, especially carbohydrate and lipid levels (Fig 4). This suggests that below a certain. 
level the biochemical constituents are not readily available to fuel swimming, but are bound up in cell or structural functions (Stryer 1981). The results suggest that the level of constituents unavailable to fuel swimming is similar across the species, especially for lipid and carbohydrate.

The general pattern of utilisation seen in the present study is comparable to those recorded in studies in which the larvae and juveniles of other species have been starved to death, with large percentages of lipid and carbohydrate utilised, while protein is generally conserved (Ehrlich 1974a, b, Raae et al, 1988, Richard et al. 1991, Kramler 1992). Starvation could also have contributed to the losses observed here and to the differences among species. The heavier species were subject to starvation for a much longer time period than were the lighter species. In order to separate the cost of starvation from the cost of swimming, comparisons should be made with fish which have been starved for a period of time equal to that taken by fish to swim to exhaustion.

While the fish in the present study appear to have exhausted their available energy stores, it did not appear that they had passed 'the point of no return' (Houde 1989, Kramler 1992). Of 25 specimens retained after swimming (for identification purposes), all recovered and regained condition, indicated by an increase in weight, when fed on a diet of Artemia sp. Thus, although the fish were exhausted they were not terminally starved.

The energetic cost of swimming per gram body weight appears to decrease with increasing dry weight (Fig. 6b). This relationship agrees with previous results for larger species (Schmidt-Nielson 1972, Beamish 1978). Part of the explanation for this may lie in the difference in relative metabolic rates. Smaller species have a much greater relative metabolic rate and this must be factored into the cost of locomotion (Beamish 1978, Schmidt-Nielson 1990). Furthermore, the relative swimming speed in the larger individuals is lower, at 3 to $4 \times \mathrm{TL} \mathrm{s}^{-1}$, compared to over $6 \times \mathrm{TL} \mathrm{s}^{-1}$ for the smaller taxa. As swimming at a lower relative speed requires less energy (Beamish 1978), this may contribute to the observed decrease in cost with increasing size. The Reynolds number at which the fish swim will also change with size, influencing factors such as drag (Vogel 1994), and may also contribute to the observed differences.

Sustained swimming abilities across the species correlated strongly with the initial levels of energy stores (Table 3). This contrasts with studies in which the relationship between biochemical condition and burst swimming has been examined within species. These studies found that burst swimming abilities were not related to the condition of newly settled reef fish
(McCormick \& Molony 1993, McCormick \& Kerrigan 1996). It may be that condition in the late pelagic stage is more important in determining the extent to which species control their dispersal during the pelagic stage rather than their post-settlement survival.

Kerrigan (1996) has shown that the condition of recruits settling on reefs varies between species and among recruitment pulses within and between years. The extent of variation observed for Pomacentrus amboinensis within a single recruitment pulse (3.4-, 4.7-and 14.1-fold for lipid, protein and carbohydrate respectively) (Kerrigan 1996) is comparable to the differences observed after sustained swimming in the present study $(1.5-, 1.2$ - and 2.3 -fold) between the mean for swum fish and controls. The difference between the minimum levels in swum fish and the maximum levels in controls was even greater $(4.3-, 5.1$ and 9.2-fold). Furthermore, manipulations of environmental factors such as feeding (McCormick \& Molony 1992, Kerrigan 1994) or temperature (McCormick \& Molony 1995) have produced smaller changes in biochemical constituents than seen in the present study. It appears that periods of sustained swimming by the pelagic stages, prior to settlement, could be a major factor contributing to the observed variation in condition at settlement. Given the levels of constituents observed in recruits on the reef (Kerrigan 1996) it is also possible that some recruits may have exhausted their energy stores prior to settlement.

The differences among species in energy utilisation patterns observed in the present study, along with observed variation in swimming abilities (Stobutzki \& Bellwood 1997), suggest that the late pelagic stages of coral reef fishes have a diverse range of abilities. It appears that strategies for modifying dispersal in the pelagic stage and for returning to reefs for settlement may vary greatly among taxa. It is no longer valid to assume that as the general life history strategies of reef fish are similar, the pelagic stages of reef fishes are all the same (cf. Doherty \& Fowler 1994) and that their dispersal is governed by uniform processes.

Acknowledgements. I thank D. Bellwood for advice and support during this project; the Lizard lsland Research Station for field support; B. Molony for instruction in the brochemical techniques; L. Linton for completing the assays; S. French, J. Morgan, J. Ackerman, F. Lee, C. Jordan and P. Herald for field assistance; M. Milicich and J. Leis for assistance collecting and identifying fish; P. Southgate for advice on the interpretation and $\mathrm{D}$. Bellwood and B. Molony for providing valuable comments on the manuscript. Thıs work was funded by an Australian Post-Graduate Priority Research Award, Lizard Island PhD Fellowship, Australian Federation of University Women Bursary, GBRMPA Augmentative Grant, JCU Merit Research Grants and Merit Research Awards. 
Appendix 1. Mean (SE) condition factor, body weight, levels of constituents and energy levels of each species, for controls and swum fish, and the differences between these. Condition factor $=100 \mathrm{~W} / \mathrm{L}^{3}$ (Kramler 1992). + indicates an apparent increase

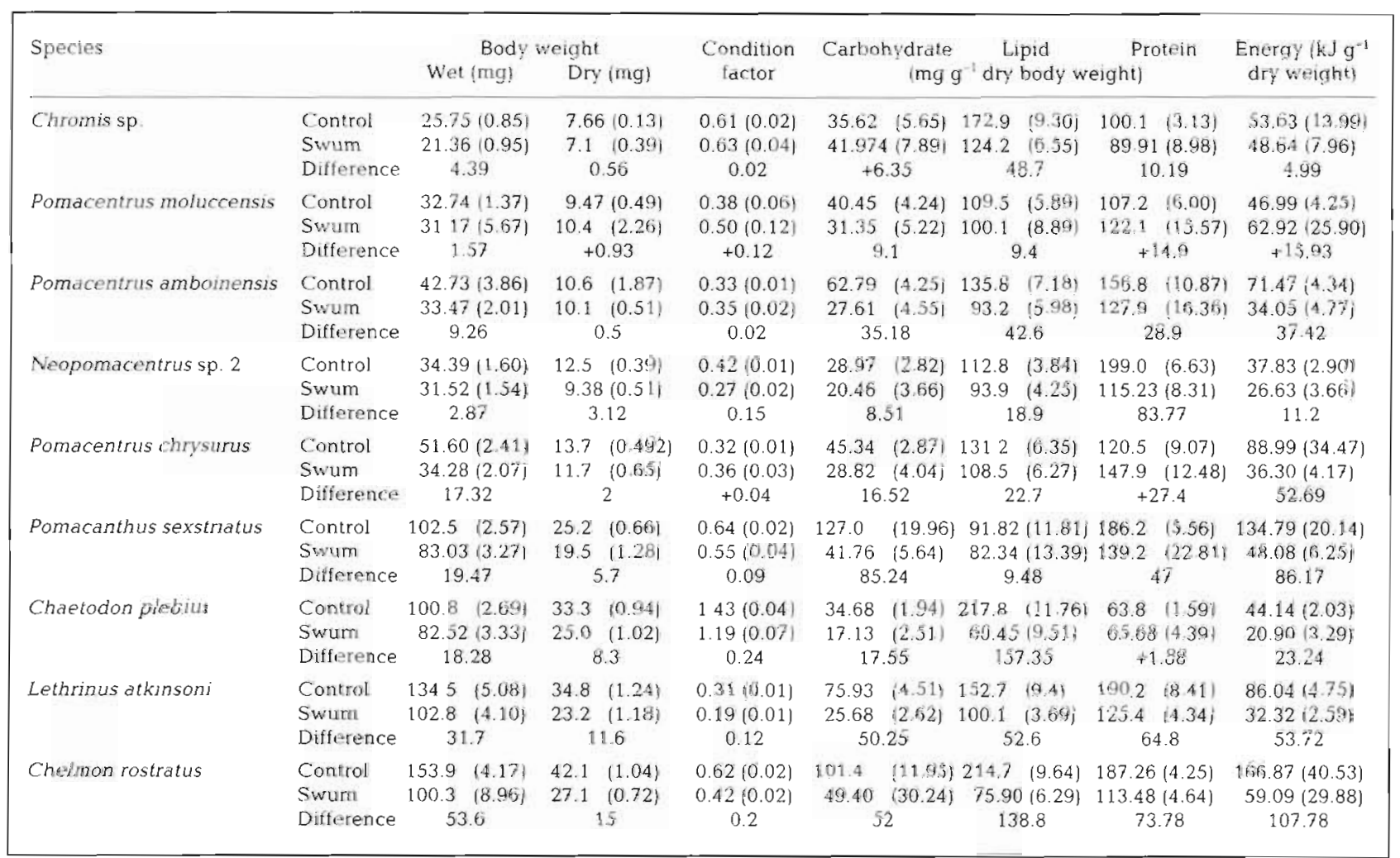

\section{LITERATURE CITED}

Beamish FWH (1978) Swimming capacity. In: Hoar WS, Randall DJ (eds) Fish physiology, Vol Vil. Academic Press, London, p 101-189

Beamish FWH (1990) Swimming metabolism and temperature in juvenile walleye, Stizostedion vitreum vitreum. Environ Biol Fish 27:309-314

Beyer JE (1989) Recruitment stability and survival-simple size-specific theory with examples from the early life dynamics of marine fish. Dana 7:45-147

Bilinski E (1974) Blochemical aspects of fish swimming. In: Malins DC, Sargent JR (eds) Biochemucal and biophysical perspectives in marine biology, Vol 1 Academic Press, London, p 239-289

Bradford MM (1976) A rapid and sensitive method for the quantisation of microgram quantities of protein utilising the principle of protem-dye binding. Analyt Biochem 72:248-254

Brett JR, Groves TD (1979) Physiological energetics. In: Hoar WS, Randall DJ (eds) Fish physılogy, Vol VII. Academic Press, London, p 279-351

Chambers RC, Leggett WC, Brown JA (1988) Variation in and among early life history tralts of laboratory-reared winter flounder Pseudopleuronectes americanus. Mar Ecol Prog Ser 47:1-15

Dabrowski K, Takashima F, Law YK (1986) Bioenergetic model of planktivorous fish feeding, growth and metabolism: theoretical optimum swimming speed of fish larvae. J Fish Biol 32:443-458

Doherty PJ, Fowler A (1994) An empirical test of recruitment limitation in a coral reef fish. Science 263:935-939
Ehrlich KF (1974a) Chemical changes during growth and starvation of herring larvae. In: Blaxter JHS (ed) The early life history of fish. Springer-Verlag, Berlin, p 301-324

Ehrlich KF (1974b) Chemical changes during growth and starvation of larval Pleuronectes platessa. Mar Biol 24 : $30-48$

Ferron A, Leggett WC (1994) An appraisal of condition measures for marine fish larvae. Adv Mar Biol 30:217-303

Frith CA, Leis JM, Goldman B (1986) Currents in the Lizard Island region of the Great Barrier Reef lagoon and their relevance to potential movements of larvae. Coral Reefs 5:81-92

Houde ED (1989) Subtleties and episodes in the early life of fishes. J Fish Biol 35 (Suppl A):29-38

Kerrigan BA (1994) Post-settlement growth and body composition in relation to food availability in a juvenile tropical reef fish. Mar Ecol Prog Ser 111:7=15

Kerrigan BA (1996) Temporal patterns in size and condition at settlement in two tropical reef fishes (Pomacentridae: Pomacentrus amboinensis and $P$. nagasakiensis). Mar Ecol Prog Ser 135:27-41

Kramler E (1992) Early life history of fish: an energetics approach. Chapman \& Hall, London

Krueger HM, Saddler JB, Chapman GA, Tinsley IJ, Lowry RR (1968) Bioenergetics, exercise and fatty acids of fish. Amer Zool 8:119-129

Leis JM (1991) The pelagic stage of reef fishes: the larval biology of coral reef fishes. In: Sale PF (ed) The ecology of fishes on coral reefs. Academic Press, San Diego, p 183-230

Lindsey CC (1978) Form, function and locomotory habits in fish. In: Hoar WS, Randall DJ (eds) Fish physiology, Vol VII. Academic Press, London, p 1-99 
Loughna PT, Goldspink G (1984) The effects of starvation upon protein turnover in red and white myotomal muscle of rainbow trout. J Fish Biol 25:223-230

Love RM (1970) The chemical biology of fishes. Academic Press, London

Mann R, Gallager SM (1985) Physiological and biochemical energetics of larvae of Teredo navalis $\mathrm{L}$. and Bankia gouldi (Bartsch) (Bivalvia: Teredinidae). J Exp Mar Biol Ecol 85:211-228

McCormick MI, Kerrigan BA (1996) Predation and its influence on the condition of a newly settled tropical demersal fish. Mar Freshwater Res 47:557-562

McCormick MI, Molony BW (1992) Effects of feeding history on the growth characteristics of a reef fish at settlement Mar Biol 114:165-173

McCormick MI, Molony BW (1993) Quality of the reef fish Upeneus tragula (Mullidae) at settlement: is size a good indicator of condition? Mar Ecol Prog Ser 98:45-54

McCormick MI, Molony BW (1995) Influence of water temperature during the larval stage on size, age and body condition of a tropical reef fish at settlement. Mar Ecol Prog Ser 118:59-68

Miller TJ, Crowder LB, Rice JA, Marschall EA (1988) Larval size and recruitment mechanisms in fishes: toward a conceptual framework. Can J Fish Aquat Sci 45:1657-1670

Raae AJ, Opstad I, Kvenseth P, Walther BT (1988) RNA. DNA

This article was presented by R. N. Hughes (Senior Editorial Advisor), Bangor, United Kingdom and protein during early development in feeding and starved cod (Gadus morhua L.) larvae. Aquaculture 73 247-259

Richard $\mathrm{P}$, Bergeron J, Boulhic M, Galois R, Person-Le Ruyet $J$ (1991) Effect of starvation on RNA, DNA and protein content of laboratory-reared larvae and juveniles of Solea solea. Mar Ecol Prog Ser 72:67-77

Sale PF (1991) Ecology of coral reef fishes. In: Sale PF (ed) The ecology of fishes on coral reefs. Academic Press, San Diego, p 3-15

Schmidt-Nielsen K (1972) Locomotion: energy cost of swimming, flying and running. Sclence 177:222-227

Schmidt-Nielson K (1990) Animal physiology. Cambridge University Press, Cambridge

Stobutzki IC, Bellwood DR (1997) Sustanned swimming abilities of the late pelagic stages of coral reef fishes. Mar Ecol Prog Ser 149:35-41

Stryer L (1981) Biochemistry, 2nd edn. WH Freeman and Co, San Francisco

Vogel S (1994) Life in moving fluids: the physical biology of flow. Princeton University Press, Princeton

Webb PW (1971) The swimming energetics of trout. II. Oxygen consumption and swimming efficiency. J Exp Biol 55 $521-540$

Zar JH (1984) Biostatistical analysis. Prentice-Hall International, London

Manuscript first received: February 3, 1997

Revised version accepted: April 25, 1997 